\title{
Reward Management Strategies and Employee Performance in Selected Universities in Nakuru County, Kenya
}

\author{
Mary Wambui Kathombe ${ }^{1}$, Simon Kipchumba ${ }^{1}$, Kibet Kirui ${ }^{2}$ \\ ${ }^{1}$ Faculty of Commerce, Egerton University, Njoro, Kenya \\ ${ }^{2}$ School of Business, Nairobi University, Nairobi, Kenya
}

Email address:

wemmar@gmail.com (M. W. Kathombe),kipchumba7@gmail.com (S. Kipchumba), robertkirui98@gmail.com (K. Kirui)

\section{To cite this article:}

Mary Wambui Kathombe, Simon Kipchumba, Kibet Kirui. Reward Management Strategies and Employee Performance in Selected Universities in Nakuru County, Kenya. Journal of Human Resource Management. Vol. 6, No. 3, 2018, pp. 95-102. doi: $10.11648 /$ j.jhrm.20180603.12

Received: August 12, 2018; Accepted: September 21, 2018; Published: November 6, 2018

\begin{abstract}
Motivation plays an important role in increasing employee job satisfaction resulting in improving organizational performance. The background of the study tries to explain the motivators, both financial and non-financial. With support from empirical studies, there is a perplexing issue on what actually motives employees. The objective of the study was to establish the relationship between motivational strategies and employee performance in Kenyan universities. The specific objectives were to determine the effect of financial rewards on employee performance, to determine the effect of non-financial rewards on employee performance and to determine the combined effect of financial and non-financial rewards on employee performance. The study adopted a descriptive survey design targeting 620 lecturers in two universities in Kenya namely; Egerton and Kabarak Universities. Proportionate stratified sampling technique was used to select a sample size of 171 Lecturers. Primary data was collected using a questionnaire. Collected data was analysed using both regression and correlation analysis. The result established that there is a strong positive statistical association between combined effect of financial and non-financial rewards on employees' performance. The study concludes that financial rewards have an implication on employee performance.
\end{abstract}

Keywords: Motivation, Strategies, Performance

\section{Introduction}

Managers apply motivational theories of management in directing employees towards the organizational goals. A good reward system that focuses on rewarding employees and their teams serves as a driving force for employees to have higher performance and hence end up accomplishing the organizational goals and objectives. The current era is highly competitive and universities are facing employee retention challenges. Human resources or employees are the most central parts so they need to be influenced and persuaded towards task fulfillments. For achieving prosperity, universities design different strategies to compete with their competitors and for increasing their performance. Unless employees are motivated and encouraged to fulfill their tasks, universities cannot progress or achieve success. Employee motivation is one of the policies of managers to increase effectual job management amongst employees in organizations [1]. A motivated employee is responsive of the definite goals and objectives he/she must achieve. Motivation formulates an organization more successful because provoked employees are constantly looking for improved practices to do a work, so it is essential for organizations to motivate their employees [2].

Motivation can be done through rewarding employees using either financial or non-financial rewards. Employees expect financial and non-financial rewards for their services and efforts. In the absence of equitable pay, training and development opportunities and recognition, employees get dissatisfied and do not perform to the standards [3]. The dissatisfaction resulting from the unavailability of financial and non-financial rewards usually leads to employee turnover and poor performance. The benefits employees foresee for themselves and their families motivate them to give their 
best. Financial rewards are also known as intrinsic rewards and include pay/salaries/wages, bonuses, allowances, insurance, incentives, promotions and job security. Nonfinancial rewards, also known as extrinsic rewards include appreciation and recognition, meeting new challenges and caring attitude from the employer.

In Nigeria, interest in effective use of rewards to influence workers performance to motivate them began in the 1970s. Employee's satisfaction is important in performance. The performance of workers has become important due to the increasing concern of human resources experts about the level of output obtained from workers due to poor remuneration [4-6]. In Nigeria, teachers' motivation is very poor as they are dissatisfied with their working environment and salary conditions [7]. In Kenya, few public organizations had put in place specific programmes for motivating employees. Motivation of employees was essential in improving employees' work performance. In addition, ability to perform is not enough for effective performance. Employees have to be motivated for them to realize their maximum potential. Unmotivated lecturers do not attend classes regularly, do not cover the hours allocated for teaching, others give handouts to students to read on their own so that they can have more time for part-timing in other colleges/universities [8].

Motivation is one of the strategies used by human resources managers for attracting and retaining employees as well as facilitating them to improve their performance. Both external and internal motivations are keys in productivity of employees. There is a statistically direct significant and positive relationship between rewards and motivation [9]. Numerous other factors besides rewards influence employee performance. These include employee-working conditions, employees' relationships with their employer, job security, training and development, and the policies that guide rewards for employees [10]. However, organizations' reward systems have both positive and negative effects on employee performance [10-12]. According to these studies, there seems to be perplexing perspective on what actually motivate employees.

\section{Literature Review}

Since performance of employees drives organizations' success, it is imperative to motivate employees. Since organizations have to perform optimally and compete effectively, they must maximize on the resources they have, one of which is the human asset and the most important asset any competitive organization can possess [25]. A desired goal and target may only be achieved effectively if the workforce gets a sense of mutual gain of the organization with the achievement of a defined performance target [9]. On the other hand, an effective reward system is one that seeks to meet the employees' specific needs. However, an employee who has already achieved his/her basic needs through monetary reward, tend to value rewards that reinforce his or her self-actualization and hence will be more motivated by relational rewards [26].

Managers use motivation to attract and retain employees as well as facilitating them to improve their performance. When employees are motivated, they get work done and tend to exceed their target [13]. Lecturers' motivation is very important because it improves their skills and knowledge and it directly influences the student's achievement [14]. Motivated employees are more productive, happier, and stay with the organization longer. A great deal of the way employees behave is influenced by the way they are rewarded [15]. Similarly, reward systems and recognition are consistently acknowledged by organizations and managers as an important element in motivating individual employee [16]. In addition, workers have needs that a workplace must fulfill in order to avoid demotivation. Many Organizations face challenges of retaining employees due to limited opportunities for advancement and the current competitive labour market [17]. Loss of employees represents loss of skills, knowledge and experiences and can create a significant economic impact and cost to organizations as well as affecting the needs of clients.

Employee performance is a function of ability and motivation, whereby ability is comprised of the skills, training and resources required for performing a task. Motivation is described as an inner force that drives individual to act towards something. Rewards play a vital role in determining the significant performance in job and that it is positively associated with the process of motivation and work performance [18]. Human resources are an indispensable asset that ensures the productivity, performance and prosperity of the organization. Motivated employees are contented, dedicated and work enthusiastically [19]. Once pay exceeds a subsistence level, intrinsic factors are stronger motivators, and staff motivation requires intrinsic rewards such as satisfaction at doing a good job and a sense of doing something worthwhile [20]. However, financial rewards is not the key motivating factor and financial results have a de-motivating effect among employee $[21,22]$. In addition, non-monetary types of rewards can be very meaningful to employees and very motivating for performance improvement. Creative use of personalized nonmonetary rewards reinforces positive behaviours and improves employee retention and performance [3].

Both social and economic conditions of lecturers have an effect on their performance like low salary, lack of facilities, status of lecturers in society, lecturer's mental health and morale, stress of work, relation with other staff and management, and working environment [23]. The feeling of lecturers while doing different activities every day and concluded that if the activities related to their work, their level of motivation increased [13]. Mostly lecturers felt that they were paid less salary according to their knowledge, skills and capabilities for doing their job [24]. The primary reason most individuals work is money. They argue that while money cannot be the sole motivator, failure to use money as a motivator will significantly decrease employee productivity. Salary or pay is a significant factor that affects 
employee motivation. They observed that there is direct and positive relationship between rewards and employee work motivation. Employees should view payment systems as fair and proportionate with their skills $[25,26]$.

Money is also influential for fulfilling employees' nonmonetary needs such as authority, rank and belongingness with preferred groups. People who have more money are more powerful in society as compared to those who have lesser money. Money has symbolic value due to its perceived relationship to prestige, status, and other factors [26]. The presence of money may not be a very good motivator; the absence of it is a strong de-motivator. High employee performance followed by high monetary reward will make future high performance more likely. There is a significant and positive relationship between extrinsic rewards and employee motivation. Pay is a significant factor that affects employee motivation [27-30].

In order to develop skills and abilities specific to the company, it is significant from an organizational perspective to retain employees for a long period and promote them in accordance to their abilities [32]. However, not only seniority of long service or experience that deserves promotion but promotions should be a reward to encourage those employees who make a successful effort to increase their knowledge or skill [33].

Promotion opportunities increase the level of individual performance and organizational commitment among workers in their career advancement influences the workers' behaviours and attitudes such as motivation and organizational commitment, particularly in the case of stable employment [34, 35]. Promotions should be a reward to encourage those employees who make a successful effort to increase their knowledge or skill [34]. However, newly appointed employee may find an attractive prospect, but his expectancy of gaining promotion could be low, if he perceives that promotion is attained primarily on length of service. In such a situation, performance does not lead to rewards, so effort in that direction is not seen as worthwhile [37].

Employees that perceived promotion decisions as fair are more likely to be committed to the organization, experience career satisfaction, perform better and subsequently have a lower intention to leave the organization [46]. Upholding the same argument, many lecturers will consider leaving the institutions where they work if they do not have equal promotion opportunities as offered by other universities, particularly young lecturers who are looking for more work experiences from various institutions before deciding to remain with a particular institution. Lecturers in private institutions were more satisfied with their promotional opportunities than in public universities [47].

In addition, incentives are forms of rewards that organizations use to reward employees for exemplary performance. They include honorarium, medical allowance, insurance, bonus, commuting allowance that employees are awarded on top of their salaries [37, 38]. In the case of universities, lecturers who exceed their allocated teaching hours are paid extra cash to motivate them. Lecturers who exceed a certain number of scripts are also paid extra cash that serves as a bonus [39]. Piece rates, commissions, tips, bonuses, stock options and others, offered by employers, including health, life and dental insurance, retirement plans, maternity leave or childcare provision could give a big impact towards the performance and commitment of the employees. However, bonuses are based on individual performance, and does not increase employees' base pay and therefore are not permanent [38].

Employee training plays a vital role in improving performance as well as increasing productivity. Training has been proved to generate performance improvement related benefits for the employee as well as for the organization by positively influencing employee performance through the development of employee knowledge, skills, ability, competencies and behavior [40]. Universities organize training programs for their employees, whose major goal is to enable the lecturers improve teaching methods and enhance their performance. Short-term training contributes to individual's personal development, increases their productivity and income participation work [41]. Training contributes to improved performance of lecturers who undertake them [42].

Public Universities can support lecturer's career development initiatives through supportive leadership, creation of opportunities for organizational learning, funding career development programmes, offering incentives to those undertaking career developments [43]. University academic staff's performance can be measured through the extent to which they effectively teach allocated workloads, attendance of learned conferences, publication of books and journal articles and furtherance of academic and professional qualifications [44]. Failure by organizations to invest systematically in training and development of its employees hurts industrial development and impedes improvement in labour productivity [45].

\section{Methodology}

The study adopted a descriptive research design. The target population of the study consisted of lecturers of Kabarak and Egerton Universities. The university lecturers are Masters and Doctor of Philosophy (PhD) degree holders. There are 94 lecturers in Kabarak University and 526 lecturers in Egerton University. The study used purposive sampling to select two universities in Kenya. A sample size of 242 academic staffs were selected. These comprised of 14 full professors, 25 associate professors, 33 senior Lecturers, 107 lecturers, and 63 assistant lecturers. Primary data was collected using a questionnaire.

Data obtained was processed with the aid of the Statistical Package for Social Science (SPSS), version 21 a computer program for windows. Correlation analysis will be used to test the relationship among the variables. Descriptive statistics such as frequencies, Percentages and standard deviation will be generated to explain various attributes of 
the respondents under study. Inferential statistics such as Pearson's product moment correlation (r) and multiple regression analysis will be used to ascertain effect of variables.

The following model was used to measure the effects.

$$
Y=a+\beta_{1} X_{1}+\beta_{2} X_{2}+\varepsilon
$$

Where $\mathrm{Y}=$ Dependent variable (Employee Performance) $\mathrm{a}=$ Constant

$\mathrm{X}_{1}$

$\mathrm{X}_{2}$

$\beta_{1}$ - Is $\mathrm{R}$ coefficient between financial reward and work performance

$\beta_{2}$ - Is Regression coefficient between non-financial rewards and work performance

$\varepsilon=$ error term not captured by the model

\section{Results and Discussion}

A response rate of 70 per cent was arrived at. According to the findings, out of the 242 questionnaires distributed to the respondents, only 171 questionnaires were returned. This was adequate in carrying out analysis in line with the study objective.

\subsection{Hypotheses Testing}

The researcher used inferential statistics in testing the hypotheses that included Correlation and Multiple Regression analysis. Pearson product correlation was used to establish whether there existed significant relationships between financial and financial rewards and work performance of university employees.

\subsection{Relationship Between Financial Rewards and Work}

The study established the association between financial rewards measurements and employee performance. The financial rewards include salary, promotional pay and incentives. The mean response of salary, promotional pay and incentives were computed and correlated with a computed mean of employee performance. Their correlation coefficients are depicted in the Table 1.

Table 1. Financial Rewards and Employee Performance Correlation Matrix.

\begin{tabular}{|c|c|c|c|c|c|}
\hline & & Salary & Promotional pay & Incentives & Performance indicators \\
\hline \multirow{3}{*}{ Salary } & Pearson Correlation & 1 & $.341^{* *}$ & $.610^{* *}$ & $.862^{* *}$ \\
\hline & Sig. (2-tailed) & & .000 & .000 & .000 \\
\hline & $\mathrm{N}$ & 171 & 171 & 171 & 171 \\
\hline \multirow{3}{*}{ Promotional pay } & Pearson Correlation & $.341^{* *}$ & 1 & $.224^{* *}$ & $.454^{* *}$ \\
\hline & Sig. (2-tailed) & .000 & & .003 & .000 \\
\hline & $\mathrm{N}$ & 171 & 171 & 171 & 171 \\
\hline \multirow{2}{*}{ Incentives } & Pearson Correlation & $.610^{* *}$ & $.224^{* *}$ & 1 & $.547^{* *}$ \\
\hline & $\mathrm{N}$ & 171 & 171 & 171 & 171 \\
\hline \multirow{3}{*}{ Performance indicators } & Pearson Correlation & $.862^{* *}$ & $.454^{* *}$ & $.547^{* *}$ & 1 \\
\hline & Sig. (2-tailed) & .000 & .000 & .000 & \\
\hline & $\mathrm{N}$ & 171 & 171 & 171 & 171 \\
\hline
\end{tabular}

** Correlation is significant at the 0.01 level (2-tailed). Source: Field Data (2016)

Based on Table 1, the results revealed that there is a strong statistically significant positive relationship of $(r=0.862, \mathrm{p}<$ $0.05)$ between salary and employee performance measurement indicator. Moderate statistically significant positive relationship of $(\mathrm{r}=0.454, \mathrm{p}<0.05)$ exist between promotional pay and employee performance measurement indicator. Similarly, moderate statistically significant positive relationship of $(\mathrm{r}=0.547, \mathrm{p}<0.05)$ exist between incentives as employee performance measurement indicator. Salary or pay is a significant factor, which affects employee motivation [46]. Salary must be closely linked to the performance according to high achievers [26]. In addition, employees that perceived promotion decisions as fair are more likely to be committed to the organization [48]. That many lecturers will consider leaving the institutions where they work if they do not have equal promotion opportunities as offered by other universities. Employee incentives can be a source of competitive advantage [1].

\subsection{Relationship Between Non-Financial Rewards and Work Performance of University Employees}

The study squared up the association between nonfinancial rewards measurements and employee performance. The non-financial rewards include training, job enrichment, career advancement and work environment. The mean response of training, job enrichment, career advancement and work environment was computed and correlated with a computed mean of employee performance.

Table 2. Non-Financial Rewards and Employee Performance Correlation Matrix.

\begin{tabular}{|c|c|c|c|c|c|c|}
\hline & & Training & Job enrichment & $\begin{array}{l}\text { Career } \\
\text { advancement }\end{array}$ & $\begin{array}{l}\text { Work } \\
\text { environment }\end{array}$ & $\begin{array}{l}\text { Performance } \\
\text { indicators }\end{array}$ \\
\hline \multirow[b]{2}{*}{ Training } & Pearson Correlation & 1 & $.492^{* *}$ & $-.391^{* *}$ & .076 & $.844^{* *}$ \\
\hline & Sig. (2-tailed) & & .000 & .000 & .325 & .000 \\
\hline Job enrichment & Pearson Correlation & $.492^{* *}$ & 1 & $-.153^{*}$ & $.151^{*}$ & $.569^{* *}$ \\
\hline
\end{tabular}




\begin{tabular}{lllllll}
\hline & & Training & Job enrichment & $\begin{array}{l}\text { Career } \\
\text { advancement }\end{array}$ & $\begin{array}{l}\text { Work } \\
\text { environment }\end{array}$ & $\begin{array}{l}\text { Performance } \\
\text { indicators }\end{array}$ \\
\hline & Sig. (2-tailed) & .000 & & .045 & .049 & .000 \\
& N & 171 & 171 & 171 & 171 & 171 \\
Career advancement & Pearson Correlation & $-.391^{* *}$ & $-.153^{*}$ & 1 & $-.238^{* *}$ & $-.437^{* *}$ \\
& Sig. (2-tailed) & .000 & .045 & & .002 & .000 \\
& $\mathrm{~N}$ & 171 & 171 & 171 & 171 \\
Work environment & Pearson Correlation & .076 & $.151^{*}$ & $-.238^{* *}$ & 171 & -.033 \\
& Sig. (2-tailed) & .325 & .049 & .002 & 1 & .670 \\
Performance & $\mathrm{N}$ & 171 & 171 & 171 & 171 \\
indicators & Pearson Correlation & $.844^{* *}$ & $.569^{* *}$ & $-.437^{* *}$ & -.033 & 1 \\
& Sig. (2-tailed) & .000 & .000 & .000 & .670 & 171 \\
\hline
\end{tabular}

**. Correlation is significant at the 0.01 level (2-tailed).

*. Correlation is significant at the 0.05 level (2-tailed).

Source: Field Data (2016)

Based on Table 2, the results revealed that there is a strong statistical significant positive relationship of $(r=0.844$, $\mathrm{p}<0.05$ ) between training and employee performance. Moderate statistically significant positive relationship of $(\mathrm{r}=$ $0.569, \mathrm{p}<0.05$ ) exist between job enrichment and employee performance. Also, moderate statistically significant positive relationship of $(r=0.437, p=0.05)$ exist between career advancement and weak negative insignificant relationship of $(\mathrm{r}=.033, \mathrm{p}<0.05)$ exist between work environment and employee performance measurement indicator. Training has been proved to generate performance improvement related benefits for the employee as well as for the organization by positively influencing employee performance through the development of employee knowledge, skills, ability, competencies and behavior [40]. Similarly, increasing job enrichment, its dimensions in employees reinforces, boosts their job motivation and therefore leads to performance [49].

Further, there is need for institutions to play a major role in supporting employees' career development programmes to ensure reciprocal good performance from employees [50].
However, on work environment, workplace environment influences employee morale, productivity and job performance both positively and negatively. That if the work place environment is not liked by the employees, they get demotivated and their performance is affected [51]. The study found out that employees were not demotivated by their work environment.

\subsection{Correlation Between Financial and Non-Financial Rewards and Employee Performance}

The study determined the association between financial and non-financial rewards measurements and employee performance. A mean comprising of salary, promotional pay and incentives was obtained (financial rewards) and correlated with employee performance. Similarly, nonfinancial reward's mean was obtained which included training, job enrichment, career advancement, work environment, and correlated with employee performance as shown in Table 3.

Table 3. Association between Financial and Non-Financial Rewards and Employee Performance Correlation Matrix.

\begin{tabular}{lllll}
\hline & & Financial rewards & Non financial rewards & Performance indicators \\
\hline \multirow{3}{*}{ Financial rewards } & Pearson Correlation & 1 & $.568^{* *}$ & $.812^{* *}$ \\
& Sig. (2-tailed) & & .000 & .000 \\
& $\mathrm{~N}$ & 171 & 171 & 171 \\
& Pearson Correlation & $.568^{* *}$ & 1 & $.656^{* *}$ \\
Non-financial rewards & Sig. (2-tailed) & .000 & & .000 \\
& $\mathrm{~N}$ & 171 & 171 & 171 \\
& Pearson Correlation & $.812^{* *}$ & $.656^{* *}$ & 1 \\
Performance indicators & Sig. (2-tailed) & .000 & .000 & 171 \\
\hline
\end{tabular}

**. Correlation is significant at the 0.01 level (2-tailed).

Source: Field Data 2016.

Based on Table 3, the results revealed that there is a strong statistically significant positive relationship of $(r=0.812, p<$ 0.05 ) between financial rewards and employee performance measurement. Consequently, the $\mathrm{H}_{01}$, which stated that there is no statistically significant relationship between financial rewards and performance of university employees, was rejected and the alternative hypothesis, which states that there is statistically significant relationship between financial rewards and performance of Kenyan university employees, was accepted. This suggests that employee performance will be high in Kenyan universities that adopted financial rewards. Money is still the most crucial motivating factor for employees and that it makes them perform well in the company. Non-monetary rewards motivate but, after a certain point in an individual's career, money has the greater significance [31].

Based on Table 3, the result revealed that there is a strong statistically significant positive relationship of $(r=0.656, p$ 
$<0.05$ ) between non-financial rewards and employee performance measurement. Accordingly, the $\mathrm{H}_{2}$, which stated that there is no statistically significant relationship between non-financial rewards and performance of university employees, was rejected and the alternative hypothesis, which states that there is statistically significant relationship between non-financial rewards and performance of Kenyan university employees, is accepted. This suggests that employee performance will be high in Kenyan universities that adopted non-financial rewards.

Table 4. Combined Effect on Employee Performance.

\begin{tabular}{llll}
\hline Correlations & & & Combined effect \\
\hline & & Performance indicators & $.828^{* *}$ \\
Combined effect & Pearson Correlation & .000 & 171 \\
& Sig. (2-tailed) & 171 & $.828^{* *}$ \\
Performance indicators & $\mathrm{N}$ & .000 & 1 \\
& Pearson Correlation & 171 & 171 \\
\hline
\end{tabular}

**. Correlation is significant at the 0.01 level (2-tailed).

According to results in Table 4, there is a strong positive statistically association between combined effect of financial and non-financial rewards on employees' performance $(\mathrm{r}=$ $0.828, \mathrm{P}<0.05)$. The null hypothesis stated that there is no statistically significant effect of combined effect of financial and non-financial rewards on employees' performance. Therefore, we reject the null hypothesis and accept alternate hypothesis that there is a strong positive statistically significant effect between combined effect of financial and non-financial rewards on employees' performance.

\subsection{Effect of Financial and Non-Financial Reward Strategies on Employee Performance.}

The study determined the effect between both financial and non-financial reward strategies on employee performance by computing a mean for each of the independent variable and regressing against a dependent variable mean. The results of multiple regression is as shown in Table 5 .

Table 5. Multiple Regression between Financial and Non-Financial Rewards.

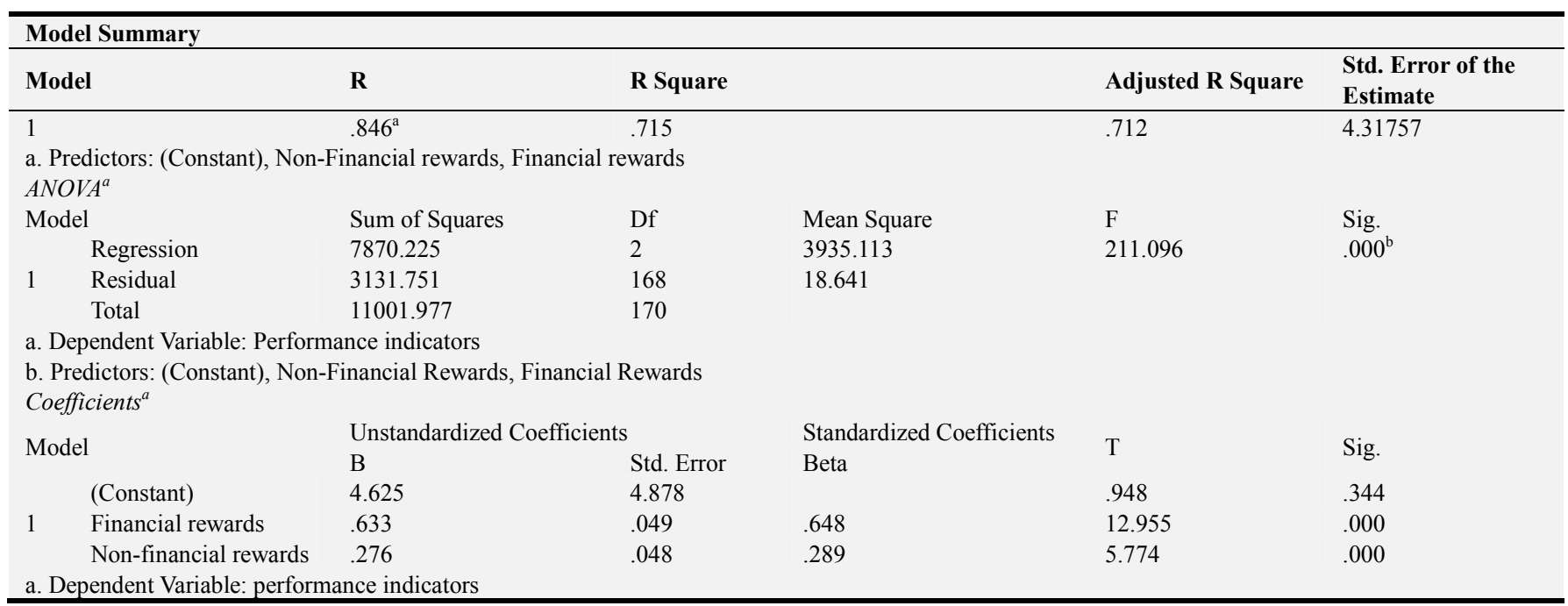

$$
\mathrm{Y}=4.625+0.633 \mathrm{X}_{1}+0.276 \mathrm{X}_{2}+4.878
$$

Table 5, shows that multiple regression coefficient of $0.633(\mathrm{r}=0.633, \mathrm{P}<0.05)$ exists between financial rewards and employee performance. This indicates that there is a strong positive relationship between financial and nonfinancial rewards on employee performance. A unit increase on financial rewards leads to 0.633 units increase in employee performance.

In addition, the multiple regression coefficient of $0.276(\mathrm{r}$ $=0.276, \mathrm{P}<0.05)$ exists between non-financial rewards and employee performance. This indicates that there is a weak positive relationship between financial and non-financial rewards on employee performance. A unit increase on nonfinancial rewards leads to 0.276 units increase in employee performance.

Rewards play a vital role in determining the significant performance in job and that it is positively associated with the process of motivation and work performance [40]. There is a statistically direct significant and positive relationship between rewards and motivation. That if rewards being offered to employees were to be altered, then there would be a corresponding change in motivation and work performance [52]. According to the findings of this study, financial and non-financial rewards motivate employees to better 
performance. Thus, employee performance will be high in Kenyan universities that adopted combined financial and non-financial reward strategies.

\section{Conclusion}

The broad objective of this study was to assess the effects of motivational strategies on employees' performance in Kenyan universities. The specific objectives of the study were: determine the effect of financial rewards on employees' performance; the effect of non-financial rewards on employees' performance; and determine the combined effect of financial and non-financial rewards on employees' performance. The findings of the study led to the following conclusions:

The study established a link between financial rewards measurements and employee performance. The findings confirm that financial rewards have an implication on employee performance. Money is still the most crucial motivating factor for employees and that it makes them perform well in the company hence higher levels of financial rewards have higher levels of employee performance.

The study also found out that there is an association between non-financial rewards measurements and employee performance except on work environment that showed a weak negative insignificant relationship of a small proportion. This is because most lecturers report to work when they have lessons unless if they need to do some academic advising or consultation and therefore work environment does not affect employee performance. Finally, the study established that the association between financial and non-financial rewards measurements and employee performance. The results indicated that there is positive significant association between financial and non-financial rewards.

\section{References}

[1] Sahoo, C. K, \& Mishra, S. (2012) Performance management benefits organizations and their employees. Human Resource Management Digest. Vol. 20, Issue 6, pp 3-5.

[2] Perry, J. L., Mesch, D., \& Paarlberg, L. (2006) 'Motivating Employees in a New Governance.

[3] Ryan, R. M. (2011). Self-determination theory and the facilitation of intrinsic motivation, social development and well. American Psychologist, 55(1), 68-79.

[4] Kayode, A. Y. 1973. "Beefing up workers productivity." The Quarterly Journal of Administration, 9: 9-15. Kulkarni, P. 1983. Organizational Behaviour and Human Decision Processes. New Delhi: McCoy Hill.

[5] Nwachukwu, C. C. (2004). "Effective Leadership and productivity. Evidence from a national survey of industrial organization". African Journal for the study of Social issues, 1:38-46.

[6] Odunlade, R. O (2012) Employee Benefits and its Effect on Employee Productivity. A Case Study of First Bank Nigeria PLC. Uyo Branch. Library, Philosophy and Practice. http://unlib.unl.edu/LPP/. Accessed on 27/06/2016.
[7] Adelabu. (2005). Teacher motivation and incentives in Nigeria.

[8] Chepkilot, R. K. (2005). The development of motivational strategies for public sector workers in Kenya. Un Publish thesis submitted to Nelson Mandela University. South Africa.

[9] Armstrong, Reilly, P., \& Brown, D., (2011). Increasing the effectiveness of reward Management, Employee Relations, Emerald Group, (33), 2, 106-120.

[10] Armstrong, M. (2012). Armstrong's Handbook of Human Resource Management Practice, 12th Ed. London Philadelphia New Delhi.

[11] Qureshi, M. I., K. Zaman and I. A. Shah, 2010. Relationship between Rewards and Employees'. Performance in the Cement Industry in Pakistan. Journal of International Academic Research, 10:19-29.

[12] Rutherford, D. G. (1990). Hotel Management and Operations. New York, NY: Van Nostrand Reinhold.

[13] Bishay, A. (1996). Teacher motivation and job satisfaction: a study employing the experience sampling method. Journal of Undergraguate Sciences, 3, 147-154.

[14] Mustafa, M., \& Othman, N. (2010). The effect of work motivation on teacher's work performance in Pekanbaru senior high schools, Riau Province, Indonesia. SOSIOHUMANIKA, 3(2), 259-272.

[15] Kaiser L. C. (2002) Job Satisfaction: A Comparison of Standard, Non Standard, and Self-Employment Patterns across Europe with a Special Note to the Gender/Job Satisfaction Paradox, EPAG Working paper, 27.

[16] Armstrong, M. \& Murlis, H. (2007). Reward Management: A handbook of remuneration strategy and practice. Revised $5^{\text {th }}$ Edition. Kogan Page Limited.

[17] Kelly, T. G. (2010). Recognition and Reward...it takes more than just a pay check. http//www.orcpa.org/pressroom/hotnews/employeerewards.ht m. Accessed, March 5th 2016

[18] Lawler, E. E. (1981). Pay and organization development. Reading, MA: Addison-Wesley.

[19] Dessler, G. (2008). Human Resource Management. New Jersey. Pearson Prentice-Hall.

[20] Finkle, L. (2011). Motivating Employee Performance Through Year End Bonuses. Retrieved from http://ezinearticles.com on 20/06/2016

[21] Pratheepkanth, P. (2011). Reward System and Its Impact on Employee Motivation in Commercial Bank of Sri Lanka Plc, In Jaffna District. Global Journal of Management and Business Research, Vol.11, No.4, 85-92.

[22] Srivastava, A., Locke, E. A. and Bartol, K. M. (2001) 'Money and Subjective Well-Being it is Not The Money, it's the Motives', Journal of personality and Social Psycholoy, 80, pp.959-917.

[23] Nadeem, M., Rana, M., Lone, A., Maqbool, S., Naz, K., \& Ali, A. (2011). Teacher's competencies and factors affecting the performance of female teachers in Bahawalpur (Southern Punjab) Pakistan. International Journal of Business and Social Science, 2(19), 1-6. 
[24] Amalki, M. J., FitzGerald, G., \& Clark, M. (2012). The relationship between quality of work life and turnover intention of primary health care nurses in Saudi Arabia. BMC health services research, 12(1), 314. http://dx.doi.org/10.1186/1472-6963-12-314 Retrieved on 26/3/2016.

[25] De Cenzo, D. A. \& Robbins, S. P. (1996). Human Resource Management. (5th. ed.)John Wiley \& Sons.

[26] Rynes, S. L., Bang, G., Kathleen, A. M., (2004). The importance of pay in employee motivation; Discrepancy between what people say and what they do. Human Resource Management, Winder, 43 (4): 381 - 394.

[27] Furnham, A., \& Argyle, M. (1998). The psychology of money. New York, NY: Routledge.

[28] Olajide, A. (2000). Getting the best out of the employees in a developing economy. A Personnel Psychology Guest Lecture Series. Department of Guidance and Counselling, University of Ibadan, Nigeria.

[29] Khan, K. U., Farooq, S. U., \& Ullah, M. I. (2010). The relationship between rewards and employee motivation in commercial banks of Pakistan. Research Journal of international studies, 14, 37-52.

[30] Hafiza, N., Shah, S., Jamseheed, H., \& Zamam, K. (2011). Relationship between Rewards and Employee Motivation in the Non-Profit Organization of Pakistan. Business Intelligence Journal, 4(2), 327-334.

[31] Agrawal, S. (2010). Motivation and Executive Compensation. The IUP Journal of Corporate Governance , 9, (Nov. $1 \& 2$ ), $27-46$.

[32] Doeringer, P. B \&. Piore, D. J. (1971). Internal labour markers and manpower analysis. Heath, Lexington M. A.

[33] Pigors,P.\& Myers, A. C. (1989). Personnel Administration, A point of view and method, 9th Ed. New York. McGraw Hill Book Company.

[34] Jacoby. S. M. (1984). Employing bureaucracy: Manager, Unions and the employees.

[35] Morishima, M. (1996). The evolution of white-collar human resource management in Japan. Advances in industrial and labor relations, 7, 145-176.

[36] Aamodt, M. G. (2007) Industrial / Organizational Psychology: An Applied Approach, Fifth Edition, Thomas Learning Inc., Belmont CA.

[37] Joseph, K., \& Kalwani, M. U. (1998). The role of bonus pay in sales force compensation plans. Industrial Marketing Management, 27: 147-159.

[38] Sturman, M. C., \& Short, J. C. (2000). Lump-sum bonus satisfaction: testing the construct validityof a new pay satisfaction dimension. Personnel Psychology, 53: 673-700.

[39] Frey, B. S., \& Jegen, R. 2001. Motivation Crowding Theory. Journal of Economic Surveys, 15(5): 589-611.

[40] Appiah, K. O., Boamah, G. K., Baryeh, D. O., Browne, N., Ferkah, A. T. and Marku-Ablerdu, T. (2013), Views of
Employees on Training and Development; A Case Study of Opportunity International Savings and Loans International (Online) http://ir.csuc.edu.gh: 8080/xmlui (Accessed on February 20, 2016).

[41] Ambetsa, A. (2006). Contribution of technical and vocational training to sustainable development. A paper presented during the $4^{\text {th }}$ Annual International Conference on Resource Utilization for Sustainable Growth and Development in the 21stcentury: Kenya.

[42] Birungi, J. K. (2002). Approaches of Academic staff development and the perceived Performance of lecturers at Uganda Martyrs University. Unpublished Masters (of Educ. Admin. \& Mgt.) dissertation, Makerere University, Kampala, Uganda.

[43] Crawshaw, J. R. (2006). Justice, source and justice content, evaluating the fairness of organizational career management practices, 16(1), 98-120.

[44] Kiriri, P. \& Gathuthi, E. (2009). Managing performance in Kenyan higher education institutions. Application of the Balanced Scorecard, Management Digest. Vol.1 pp 514-526.

[45] Alam, M., \& Farid, S. (2011). Factors affecting teachers' motivation. International Journal of Business and Social Science, 2(1), 298-304.

[46] Kalim U. K., Syed U. F \& Muahmmad I. U. (2010), 'The Relationship between Rewards and Employee Motivation in Commercial Banks of Pakistan', Research Journal of International Studies, 14, pp 70-72.

[47] Wan, H., Sulaiman, M., \& Omar, A. (2012). Procedural justice in promotion decision of managerial staff in Malaysia. Asia Pacific Business Review, 18(1), 99-121. doi:10.1080/13602380903424167.

[48] Khalid, S. \& Irshad, M. Z. \& Mahmood, B. (2011). Job Satisfaction among Academic Staff: A Comparative Analysis between Public and Private Sector Universities of Punjab, Pakistan. International Journal of Business and Management, 7(1), 126-136.

[49] Siu, O. 1., Lu, J. F., Brough, P., Lu, C. Q., Bakker, A. B., Kalliath, T. \& Lo, D. (2010). Role resources and work-family enrichment: The role of work engagement. Journal of Vocational Behavior, 77(3), 470-480. http://dx.doi.org/10.1 016/j.jvb.2010.06.007.

[50] Kamoche, K., N., Nyambegera, S. \& Mulinge, M. (2004). Human Resource Management in Kenya. In Managing HRM in Africa, Kamoche, K., Yaw, D. Horwitz, F. and Muuka, G. N. (Eds). London: Routledge.

[51] Chandrasekar, K. (2011). Workplace environment and its impact on organisational performance in public sector organisations. International Journal of Enterprise Computing and Business Systems, 1(1), 1-19.

[52] Danish, R. S. \& Usman Ali (2010). Impact of reward and recognition on job satisfaction and motivation: an empirical study from Pakistan. International Journal of Business and management; 5(2), 159-236. 